\title{
Nigeria and World Bank Global Gas Flaring Reduction (GGFR) Partnership: The Tragedy of the Commons
}

\author{
Jude C. Okafor, PhD, BL \\ Department of Political Science, Nnamdi Azikiwe University (UNIZIK), Awka, Anambra State, Nigeria \\ Ernest Toochi Aniche, $\mathrm{PhD}$ \\ Department of Political Science, Federal University, Otuoke, Bayelsa State, Nigeria, Postal Code: 650211
}

\begin{abstract}
Globally, over 150 billion cubic metres of associated gas are being flared and vented annually. Africa flares 40 billion cubic metres annually in which 35 billion cubic metres are flared in sub-Saharan Africa. In Nigeria alone, gas flaring amounts to about 23 billion cubic metres per annum in over 100 flare sites, constituting over 13 percent of global gas flaring. This translates to greenhouse gas emission of 45 million tons of $\mathrm{CO}_{2}$ out of the global total of 400 million tons annually. Nigeria partners with the GGFR, a World Bank led public-private partnership that includes major oil and gas producing countries and companies. The GGFR was established to facilitate and support national efforts to utilize currently flared gas by promoting effective regulatory framework and tackling the constraints on gas utilization. The study essentially adopts qualitative method that relies on secondary data and applies radical environmentalism a combination of Marxism, rentierism and environmentalism as theoretical framework of analysis. The paper focuses primarily on the role of Nigeria in the GGFR vis a vis other partners; and thus, concludes that oil dependence of GGFR partners undermines the enforcement of associated gas flaring and venting reduction and elimination policy in Nigeria.
\end{abstract}

Keywords: Oil, gas flaring, radical environmentalism, World Bank, GGFR, Nigeria

\section{Introduction}

Globally, over 150 billion cubic metres of natural gas are being flared and vented annually equivalent of 25 percent of the United States' gas consumption or 30 percent of the European Union's gas consumption, or more than the combined gas consumption of Central and South America, and amount to approximately 30.6 billion dollars. Out of this volume of national gas flared and vented globally, Africa contributes 40 billion cubic meters annually in which 35 billion cubic metres are flared in sub-Saharan Africa alone equivalent to half the continent's power consumption. Fewer than 20 countries account for more than 70 percent of gas flaring and venting, and just four countries put together flare about 70 billion cubic metres of associated gas, annually (Kaldany, 2006; Aniche 2015a).

Flaring of associated gas emits a greenhouse gas (GHG) which contributes to global warming and climate change. Indeed flaring of associated gas contributes to global emissions of GHGs with flaring emissions currently estimated at about 400 million tons of carbon dioxide into the atmosphere each year. Flaring and venting of gas in petroleum production, therefore, wastes a valuable energy resource worth approximately 30.6 billion dollars each year, harms the environment and as well contribute to a global climate change by adding some 400 million tons of carbon dioxide $\left(\mathrm{CO}_{2}\right)$ in annual emissions (Ismail and Umukoro, 2012). Although, the environmental effect of gas flaring is transboundary in terms of global warming and climate change, it has some negative effects on the immediate environment leading to local and global concerns.

In Nigeria alone, gas flaring amounts to about 23 billion cubic metres per annum of the gas generated in association with crude oil production in over 100 flare sites, constituting over 13 percent of global gas flaring, which translates to GHG emissions of 45 million tons $\mathrm{CO}_{2}$ equivalent out of the global total of 400 million tons. Consequently, Nigeria has lost about $\$ 72$ billion in revenue for the period between 1970 and 2006 or about $\$ 2.5$ billion annually on the average for flaring associated gas (Aniche, 2014). Nigerian government has set various deadlines for elimination of gas flaring but none of these zero gas flaring deadlines has been achieved. Even before the formation of GGFR in 2002, a number of efforts have been made by the Nigerian government to reduce gas flaring with little progress (Agboola, et al, 2011; Kingston, 2011). GGFR is assisting Nigeria in achieving gas flare out, or at least, significantly reducing gas flaring since 2003. The objective of this study is to assess the role of Nigerian state and NNPC in the World Bank GGFR towards enforcement of associated gas flaring reduction and elimination policy in Nigeria.

\section{An Overview of the World Bank Global Gas Flaring Reduction (GGFR) Initiative}

The GGFR was launched by World Bank in 2002 in collaboration with Norway at a conference titled World Summit on Sustainable Development held in Johannesburg, South Africa in August 2002. GGFR is made up of country partners, oil and gas multinational partners and international organizations including international nongovernmental organizations of which Nigeria and Nigerian National Petroleum Corporation (NNPC) are partners 
(see Table 1 below). Actually, Nigeria joined the GGFR partnership at the inception in 2002 as a pioneer member. GGFR partnership involves oil producing countries, including Nigeria state-owned oil companies called NNPC, major international oil companies (IOCs) and international organizations such as the World Bank and Organization of Petroleum Exporting Countries (OPEC). NNPC represents other oil and gas multinational operators in Nigeria as part of the joint venture partnership arrangement. Together, the Global Gas Flaring Reduction (GGFR) partner countries contribute over $70 \%$ of the global gas flaring (Aniche, 2015b).

The World Bank led Global Gas Flaring Reduction (GGFR) partnership initiative is one of the international initiatives aimed at significantly reducing global gas flaring and venting which stood at over 150 billion cubic metres per annum between 2002 and 2005. Nigeria as one of the World Bank GGFR partners contributes about $13 \%$ of total global gas flaring amounting to over 23 billion cubic metres enough to meet Nigeria's total energy needs. The World Bank GGFR is assisting partners like Nigeria in significantly reducing their contributions to global gas flaring through promoting effective regulatory frameworks and tackling the constraints on gas utilization (Aniche, 2014).

In 2010, the partnership achieved a milestone with satellite data estimating a $9 \%$ drop in gas flaring globally. Between 2009 and 2010, there was a reduction from 147 billion cubic metres (bcm) to 138 bcm despite a two billion barrels-a-day increase in crude oil production over the same period translating to a roughly $15 \%$ drop in gas flaring intensity since 2002. Also, between 2005 and 2011, gas flaring decreased by approximately $20 \%$ from $172 \mathrm{bcm}$ to $140 \mathrm{bcm}$ based on satellites estimate commissioned by GGFR. This amounts to $32 \mathrm{bcm}$ decrease roughly equivalent to 85 million tons of $\mathrm{CO}_{2}$ emissions (Svensson and Rios, 2012).

However, the remaining $140 \mathrm{bcm}$ of associated gas flared in 2011 globally amounts to 360 million tons of $\mathrm{CO}_{2}$ emissions and equivalent to almost one-third of European Union's annual natural gas consumptions. It is perhaps pertinent to note that most of these estimated reductions were recorded in Nigeria, Russia and Kazakhstan where public and private stakeholders have increased investment in associated gas utilization projects. Yet Russia and Nigeria still top the list of twenty most flaring countries in 2011 (Aniche, 2015b).

The GGFR partners aim to overcome the barriers to gas flaring reduction by sharing international best practices and implementing country-specific programs. As such, the GGFR partners established a collaborative and voluntary global standard for gas flaring reduction known as the Voluntary Standard. The voluntary standard provides a framework for governments, companies and other stakeholders to consult each other in collaborative actions on projects across two or more countries to reduce barriers to associated gas utilization (see Table 2 below). The GGFR partners are determined to avoid flaring from new oil projects and to eliminate continuous production flaring unless where no economic alternatives exist (Svensson and Rios, 2012).

Some of these barriers to gas flare reduction include the high cost of gathering and utilizing the associated gas, undeveloped domestic gas markets and limited access to international markets, lack of financing of gas infrastructure, poor regulatory frameworks and inefficient gas pricing systems mainly due to subsidies (Christiansen and Haugland, 2001; Dayo, 2008; Ogbara, 2009; Oluduro, 2011). The GGFR helps countries and companies overcome these barriers by focusing on commercialization of associated gas through identification of potential uses, regulatory framework for flaring and venting, implementation of the Voluntary Global Standard for flaring and venting reduction, capacity building for obtaining carbon credits for financing flaring and venting reduction projects (World Bank, 2004a).

Global Gas Venting and Flaring Reduction Voluntary Standard which was endorsed by GGFR partners in May 2002 outlines a plan of action for gas flaring reduction and elimination including adoption within one year by partner countries and companies. The Voluntary Global Standard is complemented by the CDM. The CDM stimulates investments in gas flaring reductions and associated gas utilization (GGFR, 2004; World Bank, 2005). However, CDM is limited by financial viability threshold even when it is tailored to the special needs of commercial gas flaring reduction projects with acceptable economic rate of return factoring social costs of $\mathrm{CO}_{2}$ emission reduction. For current gas flaring reduction CDM, see Table 3 below.

In addition, World Bank's Prototype Carbon Fund was meant to help lower the costs of effective upstream and downstream gas flaring projects. The Fund is designed to finance projects that can be expected to receive credits for reducing GHGs under the various Kyoto mechanisms like clean development mechanism (CDM) and Joint Implementation (JI) (see Table 4 below). Most oil companies complained that impact of these green financing mechanisms on project economics was marginal though they admitted that in some cases the mechanisms could enable the project to meet the required threshold. Most flaring reduction projects hardly meet the standards of an emission reduction project under one of the Kyoto mechanisms, and thus, received little attention in the context of the Protocol. The toughest hurdle seems to be additionality test meaning that the projects sponsors would have to show that emissions reductions engendered by the project would not otherwise have occurred. This is a challenge to countries like Nigeria and companies like NNPC that already have formulated policies for gas flaring elimination (Aniche, 2015c). 


\section{Radical Environmentalism and the Contradictions of GGFR Partnerships}

This study is predicated on radical environmentalism. Our own brand of environmental radicalism is a blend of rentierism, Marxism and environmentalism (Aniche, 2014). Marxism demonstrates that the driving force of capitalism is not human need or social welfare or even consumer choice but the need for profit and accumulation of capital. The capitalists are compelled by competition to maximize profits and accumulation of surplus value. The inevitable logical outcome of concentration of capital is competition. Another logical outcome of the concentration of capital or capital accumulation is international competition between states acting in the interest of their respective capitalist class. This means that the world's highest energy consumers such as US, China, Europe, etc. face each other as competitors (Molyneux, 2010).

A rentier state is a term used to classify those states which derive all or a substantial portion of their revenues from the rent of indigenous resources to external clients and the creating in the same process a rentier mentality and a rentier class in these states (Beblawi and Luciani, 1987; Mahdavy, 1990). The four basic characteristics of a rentier state which are (a) rent situations must predominate in that there is no such thing as a pure rentier economy (b) the rent must come from abroad or outside the country (c) in a rentier state only the few (i.e. the rentier class) are engaged in the generation of rent while the majority is involved in its distribution and consumption meaning that the government functionaries or political leaders (i.e. rentier class) make the deals and take in the revenue, and then allocate to the public that is not involved in creation of wealth and (d) the government must be the principal recipient of the external rent in the economy meaning that the rents accrue to the government directly (Beblawi, 1990). The implications of the above characterization is that rentierism often transforms rentier states into mono-product or mono-cultural economies where (i) the little productive activities are mainly confined at the level of primary production necessary for oil exploration (ii) there is predominance of public sector over private sector (iii) there is in the private sector the dominance of informal sector over formal sector (Beblawi, 1990; Okeke and Aniche, 2013; Ifesinachi and Aniche, 2014; Okafor and Aniche, 2014).

Environmentalism advocates for the lawful preservation, conservation, restoration and improvement of the natural environment, ecology or surroundings of living things. Environmentalism is concerned with environmental protection, environmental security, environmental concerns, and improvement of the environmental health. Environmentalism deals with issues of global warming, greenhouse gas emission, climate change, etc. (McCormick, 1995; de Steiguer, 2006; Woodhouse 2009; Bakari, 2013). Environmentalists prioritize environmental costs over and above economic or monetary costs, environmental security over energy security. Environmentalists believe that human interference with nature should be restricted or minimized as a matter of urgency for the sake of living things or the earth. Eco-socialists, a blend of Marxism and environmentalism, attack the gulf between the two varieties of environmentalism. The environmentalism of the North, an aesthetic environmentalism that is the privilege of wealthy people who no longer have basic natural concerns and the environmentalism of the South, where people's local environment is a source of communal wealth as a matter of survival (Kutting, 2004; Custers, 2005; Parenti, 2005).

Thus, radical environmentalism emanating from the blend of Marxism, rentierism and environmentalism sees capitalism as a source of resource depletion and environmental degradation. The analytical utility and explanatory usefulness of the radical environmentalism in this study perhaps stem from the fact that it more than any other theory capture the very essence of global environmental politics and as well the fundamental and primary concerns of the World Bank led Global Gas Flaring Reduction (GGFR) partners. Environmental radicalism thus have high analytical and explanatory value in that it is adequate and apt for explaining the four major issues in this study.

Perhaps the failure of enforcement of associated gas flaring reduction and elimination policy in Nigeria despite the country's role in the World Bank GGFR partnerships is captured by the six main contradictions of GGFR partnerships as identified by radical environmentalism such as (i) contradiction between capital and environment or between development of productive forces of the society and the environment (ii) contradiction between rents and environment or between profits and environment (iii) conflict between economic development and sustainable development or between economic growth and environmental protection, (iv) tension between national security and environmental security, (v) contradiction between economic diplomacy and environmental diplomacy, and (vi) conflict between global energy concerns and global environmental concerns or between global energy security and global environmental security (Aniche 2015a; Ifesinachi and Aniche, 2016).

For example, contradiction between capital and environment and conflict between economic development and sustainable development as well as contradiction between economic diplomacy and environmental diplomacy, explain why the World Bank led Global Gas Flaring Reduction (GGFR) partnership is preoccupied with defending global capitalism by ensuring adoption of neo-liberal approaches like carbon financing, carbon credit, clean environment initiative and other neo-liberal strategies otherwise known as Washington Consensus such as publicprivate partnership, deregulation, liberalization, privatization, etc., to reduce gas flaring. This is to ensure undisrupted increase in world crude oil production and supply chain necessary for preventing global capitalism from imminent collapse. The consequence of increasing world crude oil supply is increasing gas flaring in mainly 
net-exporting oil producing or oil revenue dependent countries like Nigeria, because increase in oil production is not tied to increase in the capacity of associated gas gathering and utilization facilities. Moreso, the World Bank led Global Gas Flaring Reduction (GGFR) partnership does not really believe in gas flare out regime, but rather believes in gradual reduction or flare down. This coupled with its insistence on neo-liberal approaches and strategies for reducing gas flaring had not been effective in assisting Nigeria to achieve its zero-gas flaring deadline. Consequently, Orenstein (2010:7) describes the World Bank as:

The World Bank Group is an institution of contradictions. It is a major climate polluter whose loans help lock developing countries into carbon-intensive development paths for decades, yet it wants to play a leading role in mitigating that same pollution. Though the World Bank is supposed to help developing countries alleviate poverty, its practices often hurt the poor and help entrench the powerful. People in developing countries are already being forced to adapt to the impacts of the pollution the Bank helps cause, while development gains are undercut by the climate crisis. And while the institution views itself as a defender of developing country interests, the World Bank remains a political tool used by developed countries in United Nations climate negotiations to maintain control over international climate finance. As the world grapples with the scope of the climate crisis, the World Bank Group - on its own and at the behest of many developed countries - is asserting itself to play a key role in controlling funding for developing countries to adapt to the unavoidable impacts of climate change and to mitigate, or reduce, greenhouse gas emissions.

In the same vein, the contradiction between development of productive forces of the society and the environment, and as well as the conflict between global energy security and global environmental security, explain the reason why the Global Gas Flaring Reduction (GGFR) importing oil partner countries are concerned more with increase in world oil supply from net-exporting oil partner countries than in their effort to reduce gas flaring. This is because for most of these importing oil partner countries, the need for increasing world oil supply necessary for achieving short-term global energy security is more fundamental or important than global environmental security. In other words, the importing oil partner countries place much emphasis on global energy security at the expense of global environmental security in order to sustain their level of industrialization, economic growth and development and avoid collapse of their economies. Consequently, global environmental security can be sacrificed in the altar of global energy security or economic growth and development. The implication is that so long as the importing (GGFR) partner countries demand an increasing crude oil from net-exporting partner countries like Nigeria without recourse to improving the capacity of associated gas utilization capacity, the reduction in gas flaring in Nigeria will continue to be minimal or insignificant not to talk of meeting flare out deadline (Aniche, 2014).

Also, contradiction between rents and environment, conflict between economic growth and environmental protection and tension between national security and environmental security or security of the local population living in the immediate environment, explain the reason why the Nigerian state is concerned with increase in oil production and revenues more than the environmental harmful effects of gas flaring to the immediate environment in the Niger Delta. Due to the rentierism or rentier character of the Nigerian state and the associated rentier mentality of the Nigeria rentier class, Nigeria places more importance on collection of oil revenues accruing as rents or royalties more than on protecting the environment of oil communities in the Niger-Delta. Most of the oil exporting countries like Nigeria are rentier states, and as such oil-revenue-dependent. The import of this is that a country that depends largely on oil revenue to offset its expenditure cannot in all sincerity enforce zero gas flaring deadline in oil and gas multinationals. The major concern of the Nigerian state is to achieve economic growth and development through higher oil production and revenue without recourse to the capacity of associated gas utilization facility at the expense of oil communities (Aniche, 2015b).

Finally, the contradiction between capital and environment and contradiction between profits and environment, explain the reason why the Global Gas Flaring Reduction (GGFR) partnering oil and gas multinationals are driven by desire to sustain competitive edge over their competitors through increasing oil production in Nigeria in order to make more profits at the expense of the oil communities. The GGFR partnering oil and gas multinationals place priority on profits through increasing oil production more than on environmental protection. Thus, their major preoccupation has been on how to develop cutting edge technology to enhance oil recovery from oil wells and to increase deep water drilling than on developing sophisticated technology to increase the capacity of associated gas gathering facilities in Nigeria. The point being made is that the GGFR partnering oil and gas multinationals are more concerned with maximizing profits through improved and efficient crude oil production in Nigeria than developing or improving the capacity of associated gas gathering and processing facilities to meet the zero gas flaring deadline. In other words, the GGFR partnering oil and gas multinationals operating in Nigeria would not be able to meet any future gas flare out deadline so long as they are more preoccupied with the drive to sustain their competitive edge over their rivals through increase in oil production and profit maximization (Aniche, 2014). 
From the foregoing therefore radical environmentalism is able to make us understand that the fundamental concern of the World Bank led Global Gas Flaring Reduction (GGFR) partners is increase in crude oil production though for different reasons. For examples, the reason for World Bank is to promote, preserve, protect and defend global capitalism, or to prevent global capitalism from imminent collapse that may arise from the shortfall in crude oil supply or crude oil supply-demand gap or short-term shortfall in energy supply. This is evident in the fact that development and sustenance of global capitalism depends on global energy security. For Global Gas Flaring Reduction (GGFR) importing partner countries the reason is increase in crude oil supply needed to achieve global energy security, economic growth and development, and sustain industrialization. For Global Gas Flaring Reduction (GGFR) net-exporting countries like Nigeria, the reason is increase in oil revenues defined as national security, economic growth and development. Finally, for Global Gas Flaring Reduction (GGFR) partnering oil and gas multinationals in Nigeria, the reason is to increase or maximize profits, and development of productive forces of the society (Aniche, 2015a). In summary, there is contradiction between national or specific interest and global interest otherwise known as the tragedy of the commons.

\section{The Role of Nigeria in GGFR}

Gas flaring began in Nigeria under the British colonial rule when Shell began oil exploration and production soon after oil was discovered in commercial quantity in Oloibiri, now in Bayelsa State in 1956. In Nigeria, the gas flare emission limits are determined within the maximum associated gas emission levels for all upstream operations as set by the government. Nigeria like other GGFR countries regulates gas flaring and venting through primary and secondary legislations. However, the Petroleum Industry Bill (PIB) which supposed to provide a coordinated primary legislation for regulatory framework is yet to be passed by the National Assembly. The World Bank GGFR provides three main regulatory approaches for achieving flaring and venting reductions such as prescription, performance-based and hybrid approaches (Aniche, 2015b).

For instance, the prescriptive approach is based on specific and detailed gas flaring and venting regulations established by the regulator and to be met by operators. Detailed prescriptions of regulatory procedures and operational processes clarify what is required and how is to be achieved by the operators. Stringent enforcement procedures provide operators with incentives to comply with gas flaring and venting regulations. In theory, this approach, makes it relatively easy for the regulator to set targets and determine whether operators are meeting the gas flaring and venting requirements. In practice, imposing detailed technical regulations on gas flaring and venting is challenging and complicated. As a result, measuring flare and vent volumes and monitoring compliance on each oil production site may be impracticable and costly (World Bank, 2004b).

The performance-based approach places a greater emphasis on consensus and cooperation between the regulator and the operators in setting gas flaring and venting reduction targets or elimination deadlines. Thus, most GGFR countries opt for a more performance-based approach to achieve flaring and venting reduction targets. It is then the responsibility of the operators to define strategies for achieving these targets and provide evidence to show that they are complying with the agreement. To be effective, the regulator still requires enforcement powers to ensure compliance. Hybrid approach is therefore a combination, a mixture or a synthesis of prescriptive and performance-based approaches. In practice, the boundary between prescriptive and performance-based approaches is blurred (World Bank, 2004b). Some GGFR countries like Nigeria that have adopted effective or strict gas flaring and venting regulations often use a hybrid approach. Nigeria has as a matter of necessity adopted a hybrid approach due to dominance of joint venture partnerships between the NNPC and oil majors in which, the former is the regulator, investor and de facto operator. But despite adopting hybrid approach, Nigeria has not been able to effectively enforce zero gas flaring policy as demonstrated by various indices below.

No matter the approach adopted to establish an efficient regulatory regime, two key areas must be addressed such as operational processes and regulatory procedures. Operational processes help to ensure that environmental, health and safety standards are being met when operators flare and vent associated gas. Put differently, the main function of technical regulation is to specify operational processes to ensure that environmental, health and safety standards are being met when operators flare and vent associated gas. Operational standards and guidelines typically include such aspects as burning technologies and practices in which equipment and operating processes may be specified to ensure burning of 'clean' gas and efficient combustion such as timing, siting or location, heat and noise generation, and smoke and noxious odours (World Bank, 2002).

It is through timing that maximum duration of continuous flaring may be limited. Flare location or site suggests that the flare typically will have to be located at a safe distance from other facilities, accommodation units and populated areas. In heat and noise generation, upper limits may be set at specified distances from flaring operations. In the case of smoke and noxious odour, limits may be imposed on the opacity of smoke generated by flaring. An efficient burning or flaring of associated gas does not produce visible smoke. Black smoke from a flare indicates incomplete combustion (World Bank, 2004b).

On the other hand, regulatory procedures refer to a regulator's ability to monitor gas flaring and venting operations at oil production sites, measure actual flare and vent volumes, and enforce compliance with operational 
guidelines. An operator's compliance with flaring and venting guidelines depends mainly on the effectiveness of the regulatory procedures. Most GGFR oil producing net-export countries like Nigeria that adopted operational processes for gas flaring and venting lack effective regulatory procedures for monitoring, measuring and enforcing. Yet many of them have not established any operational requirements for gas flaring and venting.

In Nigeria, the regulatory framework requires that a maximum sterilized approach distance of 60 metres radius measured from the base of the stack shall be maintained and no other equipment except that related to the flare shall be located within this area. The allowable heat radiation at ground level is $6.31 \mathrm{kw} / \mathrm{m}^{2}$ during maximum flaring at a distance of 60 metres from the base of the flame. It is also specified that the noise levels for unprotected ears shall be well within the threshold of pain between 80 and 100 acoustic decibels (World Bank, 2002).

Regulatory gas flaring and venting procedures refer to dealings among the institutions or agencies that regulate gas flaring and venting, the operators, and other interested parties. Gas flaring and venting regulatory procedures are given legal effect, binding on all parties, pursuant to powers of the regulatory authority provided in relevant primary and secondary legislations. Gas flaring and venting procedures must be made public to help achieve the objective of openness and transparency. Openness refers to the ability to take part in a proceeding while transparency is ability to understand policies, laws, regulations, and related decision making procedures. Regulatory gas flaring and venting procedures refer mainly to the following procedures like applications and approval, measuring and reporting, and monitoring and enforcing (World Bank, 2004b).

Some of the efforts of Nigerian government in implementing GGFR initiatives include legal and regulatory frameworks, fiscal and economic incentives, international engagements and initiatives, and setting of zero gas flaring deadlines. In line with GGFR initiatives, Nigerian government had enacted several laws for curbing gas flaring namely the 2004 Associated Gas Re-injection (Amendment) Act, and finally, the 2010 Associated Gas Re-injection Bill. Yet oil multinationals continue to flare gas in spite of these gas flaring regulatory regimes, either because the laws are defective or that they are not properly implemented or enforced (Malumfashi, 2007; Aghalino, 2009; Ukala, 2011).

Recently, the Nigerian government introduced another authority or body called the Presidential Implementation Committee on CDM (PIC CDM) as the body to organize CDM activities in Nigeria. Also, the PIC CDM has been named the Designated National Authority (DNA) as required by the UNFCCC and as defined in the Marrakech Accords. In this capacity, the PIC CDM has complete responsibility for CDM activities, especially in areas where government intervention and activities are expected. Thus, the DNA is expected among other things to promote CDM projects in Nigeria; provide clear and flexible procedures for review and approval of CDM projects; provide documentation and communication portals that give clear information to project proponents and investors (both buyers of Certified Emission Reduction CERs and/or financials of the project) on the necessary steps or procedures to have an approved CDM project in Nigeria; provide clear guidance on national sustainability criteria that should be taken into consideration in developing CDM projects; write Letters of Approval (LoA) for projects being sent to Executive Board for review and other CDM project cycle activities, after the DNA must have carried out some reviews of the proposed CDM project; and keep a registry of CDM projects in the pipeline in Nigeria (ICF International, 2006).

Nigerian government is also engaging World Bank in its efforts to reduce and eliminate gas flaring. World Bank happens to be managing over $\$ 1$ billion funds for carbon purchase. Subsequently, in June 28, 2005, the World Bank approved a credit for the National Energy Development Project in Nigeria. The project facilitates preparatory work required to launch the main domestic transmission gas pipeline from the South to the North of Nigeria and related gas-to-power generator projects. Since then, World Bank has been assisting Nigeria directly and indirectly in gas flaring reduction. Apart from carbon financing, the World Bank assisted Nigeria in drafting its National Gas Master Plan and Natural Gas Strategy Study, Downstream Gas Bill and Fiscal Regime for Gas Bill (Ibikunle, 2006). For information on World Bank carbon financing to Nigeria see Table 5 below.

Nigerian government has been collaborating with the GGFR in its efforts to achieve gas flare out. These collaborations are in the areas of domestic gas sector policy; integration of operator plans; gas to power sector reform and implementation of the gas to power franchise model; financing of common infrastructure projects; small scale gas utilization; and use of CDM to obtain carbon credits for flare reduction projects. The GGFR has been involved in the preparation of Nigeria Gas Master Plan and Energy Sector Reform which include economic and financial viability of the gas pipelines. GGFR is also assisting Nigeria in carrying out gas pipeline engineering study and support to the implementation of the legal and regulatory framework for the gas sector and energy pricing study (Ifesinachi and Aniche, 2015).

As part of the larger effort to assist Nigeria in its efforts to reduce gas flaring and venting, the GGFR hosted a workshop in Nigeria, first of a series. The key aim of the workshop was to support the designing of financial mechanisms for gas flaring reduction projects including assisting Nigeria in obtaining carbon credit financing. The workshop helped build CDM capacity among project developers and national authorities leading to a viable pilot project. Already two projects benefited from CDM through GGFR partnership. For example, Kwale-Okpai IPP utilizes associated gas from five fields for power generation with a capacity of 480 megawatts 
using $140 \mathrm{mmscf} / \mathrm{d}$, while Afam IPP with a capacity of $650 \mathrm{MW}$ utilizes $190 \mathrm{mmscf} /$ day. Another project that may be considered is Obiafu-Obrikom Gas injection project involving the reinjection of between 270-350 mmscf/d with a potential to delay the release of the equivalence of 2.46 million tons of $\mathrm{CO}_{2} /$ year to the atmosphere (Ibikunle, 2006). For information on GGFR's flaring reduction demonstration projects from carbon finance in Nigeria, see Table 6 below.

Nigeria is one of the GGFR partners that has endorsed a voluntary standard to eliminate venting and reduce flaring significantly within five to ten years by finding commercial uses for the associated gas through increased collaboration between countries. The Standard's initial goal for flaring and venting is "no continuous flaring and venting of associated gas, unless there are no feasible alternatives". Today, the Nigerian government is implementing the GGFR's voluntary standard for reducing global gas flaring and venting with the goal of reducing barriers to the utilization of associated gas through markets and infrastructure, commercialization of associated gas, strengthening of regulations, and trading of carbon credits (Buscu-Guven, Harriss and Hartzmark, 2010).

The voluntary standard recommends consistent use of mass and energy balances to estimate gas flare and vent volumes in the existing wells, and the installation of flow metres in newly developed wells and in existing facilities with large flare volumes. The GGFR also recommends continuous metering of the gas volume flared at the source or flare gas burners and the measurement of associated gas composition and heating values essential to determining green gas emission rates (Buscu-Guven, Harriss and Hartzmark, 2010).

\section{GGFR Partners' Oil Dependence and the Failure of Enforcement of Gas Flaring Elimination Policy in Nigeria}

The GGFR partners like country partners, oil multinationals, etc., are apparently united by the need to ensure gradual flare out regime and environmental concerns, but actually both oil exporting or producing and oil consuming or importing partners have one interest in common, that is, to maintain or increase oil production or supply while ensuring gradual flare out policies though for different reasons. This is as a result of the fact that GGFR partners are oil-dependent. In other words, GGFR partnership is constituted by oil-dependent partners such as oil-revenue-dependent partners or net-exporting oil producing countries like Nigeria, etc. and their state-owned oil companies like NNPC; and oil-energy-dependent partners or (net)-importing (oil producing) countries and their privately owned oil companies operating transnationally. For example, the oil exporting partner countries in spite of rhetoric are much more interested in increasing its oil export revenue through increase oil production. Oil importing partner countries are much more concerned with energy security through increased global oil production or supply. Also, oil multinational partners are interested in maximizing profits through increased oil production. The emphasis of oil multinationals is on short-term economic or monetary benefits to themselves, and not social and environment benefits to the oil communities. Consequently, they sacrifice the environmental and health costs of flaring associated gas at the altar of short-term economic or monetary costs. Even the World Bank is working towards ensuring that global flare down will not jeopardize the level of oil production in order to prevent global economic crisis.

For example, EU member states import half of their energy needs, and this is expected to rise to $65 \%$ by 2030. Europe's energy imports come primarily from Russia and the Middle East constituting approximately $70 \%$ of the world total energy consumption. In 2005 , about $80 \%$ of the energy consumed within EU was from fossil fuels. Europe imports about $50 \%$ of its total energy supply slightly over $80 \%$ of it is oil. Europe dependence on imported energy sources is expected to grow substantially by 2020 . The European Commission estimates suggest that if current trends continue, Europe will import $65 \%$ of its total energy requirements by 2030 . GGFR partners like Russia, Norway, the Middle East and North Africa are the largest suppliers of EU energy. In 2005, Russia accounted for 29\% of the EU's oil imports (Gelb, 2006; Van Gennip 2006; Yersin, 2006; Baran, 2007: Belkin, 2008).

The last few years mark the highest rates of foreign oil imports in US history. Until recently, US consumes $24 \%$ of the global oil supply while possessing only $2 \%$ of the world's oil reserves. US has imported the majority of its crude oil supply since 1994 (Deutch, 2004). In 2008, the United States produced 1.8 billion barrels of crude oil domestically and imported over 3.6 billion barrels twice as much. Petroleum is the leading source of all energy supply in the United States at $39.8 \%$, providing $96 \%$ of transportation fuel and $44 \%$ of industrial fuel. Not until recently, The United States imports the majority of its oil from Canada, Saudi Arabia, Mexico, Venezuela and Nigeria (Deutch and Schlesinger, 2006; Podesta and Ogden, 2007; Beddor et al, 2009). It is noteworthy to state that the OPEC members used to produce approximately half of US oil supply. Without any infrastructure changes, the United States may be forced to rely more on Venezuela, Russia, Middle Eastern and African countries for fuel (Waisley, 1998).

EIA oil forecasts stated that the global incremental oil production capacity by 2020 is expected to be around 45 million barrels per day (mb/d), a 60\% increase above 1999 levels. Africa, the former Soviet Union, Latin America and the Middle East with $8 \mathrm{mb} / \mathrm{d}, 7.5 \mathrm{mb} / \mathrm{d}, 6.5 \mathrm{mb} / \mathrm{d}$ and $22 \mathrm{mb} / \mathrm{d}$; respectively, account for almost 
all of the increase. Whilst other regions such as Asia, Europe and North America will have largely constant production. A major portion of the projected incremental oil production is from Saudi Arabia where the flaring ratio is one of the world's lowest. Large increases is also expected from other Middle East countries with a high flaring ratio; and from Africa and the former Soviet Union with global high flaring ratios. Additional production capacity will as well come from new oil producing countries particularly in West Africa where there is no gas flaring history and markets for associated gas are not easy to develop. If existing regional ratios of gas flared to oil produced are maintained, the EIA forecasts for incremental oil production imply, increased levels of annual flaring of approximately $60 \%$ by 2020 (GGFR, 2004).

As such, it is estimated that the dominance of oil in global energy supply chain will continue to 2020. For example, OPEC projects that world oil demand will rise by $20 \mathrm{mb} / \mathrm{d}$ from 2008 to 2030, when it reaches almost $106 \mathrm{mb} / \mathrm{d}$. Per capita oil use in developing countries will remain far below that of the developed countries. For instance, oil use per person in North America in 2030 will still be more than ten times that of South Asia. The projected demand figures, non-OPEC supply expectations, and the increase in non-crude OPEC supply suggest that the amount of OPEC crude required will continue to rise after the medium term period, reaching just over $41 \mathrm{mb} / \mathrm{d}$ by 2030 . The share of OPEC crude in total by 2010 is $39 \%$ (Aniche, 2015a).

Consequently, global oil production and consumption have increased tremendously with corresponding increase in gas flaring at least in absolute terms. For example, Nigeria has been able to reduce gas flaring in relative terms, but not in absolute terms due to increased oil production in the recent times following the improved security situation in the Niger Delta region of the country. Thus, oil multinationals operating in Nigeria are increasingly developing new oil fields, rigs and wells without developing adequate gas utilization facilities for these oil fields. For information on total gas produced and flared (scf) 2001-2011, see Table 7 below.

The implication is that Nigeria has set various zero gas flaring deadlines, but has not been able to achieve any of them due to its inability to enforce compliance among the oil and gas multinationals operating in Nigeria in joint venture with Nigerian National Petroleum Corporation (NNPC). Bassey (2008) noted that the politics of gas flaring has seen the dates of ending gas flares being shifted as it suits the international oil corporations and the government. It has continuously been shifted from 2008 to 2009 to 2011 to 2012. For example, Table 8 below shows the estimated gas flared volumes in billion centimetre $(\mathrm{bcm})$ from satellite data in Nigeria from 2002 to 2011.

Thus, despite some reductions in gas flare achieved by Nigerian government with the help of World Bank led Global Gas Flaring Reduction, the volume of gas flared in Nigeria is increasing in absolute terms due to increase in crude oil production, whilst possibility of ever achieving zero-gas flaring deadline remains remote. Varma (2008) thus noted that the global figures as well show a small or marginal decline in global gas flaring from 157 billion cubic metres in 2006 to 147 billion cubic metres in 2007 even as some of these reductions are directly linked to gas flaring reduction efforts implemented in some GGFR partner countries around the world including Nigeria.

The focus of this study remains to assess the role of the World Bank GGFR partnership on the failure of enforcement of zero gas flaring regime in Nigeria despite the country's involvement in the initiative. From all indications therefore oil dependence of GGFR partners impedes the implementation of associated gas flaring reduction and elimination policy in Nigeria. In other words, Nigeria's partnership with the World Bank GGFR initiative is an impediment to the enforcement of associated gas flaring reduction and elimination regime.

\section{Conclusion}

So far we have been able to appraise the role of Nigeria in the World Bank GGFR in implementing or enforcing associated gas flaring reduction and elimination regime. Thus, we noted that Nigeria through NNPC is partnering with GGFR to implement the Nigerian endorsed Voluntary Standard to eliminate venting and reduce flaring significantly within five to ten years by finding commercial uses for the associated gas (AG) through increased collaboration (Aniche 2015a).

From the foregoing, the conclusion at which we arrive is that oil dependence of GGFR partners hinders the enforcement of associated gas flaring reduction and elimination policy in Nigeria. Thus, we have been able to demonstrate that this failure of enforcement of associated gas flaring reduction and elimination policy in Nigeria despite the World Bank GGFR partnerships is captured by the six main contradictions of GGFR partnerships as identified by radical environmentalism such as (i) contradiction between capital and environment (ii) contradiction between rents and environment (iii) conflict between economic growth and environmental protection, (iv) tension between national security and environmental security, (v) contradiction between economic diplomacy and environmental diplomacy, and (vi) conflict between global energy security and global environmental security (Aniche 2014). Perhaps, these contradictions are reflections of the tragedy of the commons or a condition of specific interest versus shared interest.

What is to be done? The fundamental thing to do for Nigeria and other net-exporting oil producing and 
oil-revenue-dependent countries is to diversify the revenue base of their economies necessary for reducing the excessive dependence on oil revenue by mainstreaming other domestic sources of revenue like direct tax as well as developing other sectors of the economy like manufacturing sector. The way forward for oil importing and oilenergy-dependent countries is to harness other energy resources like renewable energy or seek alternative sources of energy such as clean energy, and diversify their energy needs in order to reduce their dependence on fossil fuels like oil. This is a far reaching solution to compel the IOCs to comply with the associated gas flaring reduction and elimination policy by drastically limiting oil production to the capacity of associated gas utilization facilities.

\section{References}

Agboola, M.O., Nwulu, N.I., Egelioglu, F. and Agboola, O.P. (2011). "Gas Flaring in Nigeria: Opportunity for Household Cooking Utilization”. International Journal of Thermal and Environment Engineering, 2 (2): 69-74.

Aghalino, S.O. (2009). “Gas Flaring, Environmental Pollution and Abatement Measures in Nigeria, 1969-2001”. Journal of Sustainable Development in Africa, 11 (4): 219-238.

Aniche, E.T. (2014) "The Effects of Oil Joint Venture Partnerships on Enforcement of Zero-Gas Flaring Policy in Nigeria, 2003-2011". A Ph.D Thesis Presented to the Department of Political Science, University of Nigeria, Nsukka (UNN), January.

Aniche, E.T. (2015a). Oil Sector and Non-enforcement of Zero-gas Flaring Policy in Nigeria. Saarbrucken: Lambert Academic Publishing (LAP) and OmniScriptum GmbH \& Co. KG.

Aniche, E.T. (2015b). "International Oil Corporations (IOCs), Associated Gas Utilization Technologies and Gas Flare Elimination Strategies: Implication for Zero-Gas Flaring Regime in Nigeria”. Journal of Asian and African Social Sciences and Humanities, 1 (1): 48-64.

Aniche, E.T. (2015c). "An Assessment of the Role of Nigerian State in Enforcing Zero-Gas Flare Regime, 19792012: The Imperatives of Environmental Diplomacy". Civil and Environmental Research, 7 (12): 29-45.

Bakari, M.E. (2013). Globalization and Sustainable Development: False Twins? New Global Studies, 7 (3): 23-56.

Baran, Z. (2007). EU Energy Security: Time to End Russian Leverage. The Washington Quarterly, 30 (4): 131144.

Bassey, N. (2008) "Gas Flaring: Assaulting Communities, Jeopardizing the World”, A Paper Presented at the National Environmental Consultation Hosted by the Environmental Rights Action in Conjunction with the Federal Ministry of Environment at Reiz Hotel, Abuja on December 10-11.

Beblawi, H. (1990). "Rentier State in the Arab World". In G. Luciani (ed.) The Arab State, London: Routledge.

Beblawi, H. and Luciani, G. (1987). The Rentier State, London: Croom Helm.

Beddeor, C., Chen, W., de Leon, R., Park, S. and Weiss, D.J. (2009). Securing America's Future, Enhancing our National Security in Reducing Oil Dependence and Environmental Damage. Center for American Progress, August.

Belkin, P. (2008). The European Union's Energy Security Challenges, CRS Report for Congress, Order Code 33536, January 2.

Buzcu-Guven, B., Harriss, R. and Hertzmark, D. (2010). "Gas Flaring and Venting: Extent, Impacts and Remedies", In J. Barnes, et al (eds.) Energy Market Consequences of an Emerging US Carbon Management Policy, Energy Forum, Houston: James A. Baker III Institute for Public Policy, Rice University.

Christiansen, A.C. and Haugland, T. (2001). "Gas Flaring and Global Public Goods". the Fridtj of Nansen Institute (FNI) Report 20.

Custers, P. (2005). "Marxism and Environmental Theory". Retrieved from http://www.petercusters.nl/file on 20/09/2011.

Dayo, F.B. (2008). Clean Energy Investment in Nigeria: The Domestic Context, Manitoba: International Institute for Sustainable Development.

De Steiguer, J.E. (2006). The Origin of Modern Environmental Thought, Tucson: University of Arizona Press.

Deutch, J. (2004). "Future United States Energy Concerns". Global Science Policy Change MIT Report No. 115.

Deutch, J. and Schlesinger, J.R. (2006). "National Security Consequences of US Oil Dependence". Council on Foreign Relations Independence Task Force Report No. 58.

Gelb, B.A. (2006). Russian Oil and Gas Challenges. CRS Report for Congress, Order Code 33636, January 30.

GGFR Report No 4. A Voluntary Standard for Global Gas Flaring and Venting Reduction, May 2004.

Ibikunle, A. (2006). "Reducing Greenhouse Gas Emission: The Nigerian Approach". A Paper Delivered at OPECEU CDM Conference on September.

Ifesinachi, K. and Aniche, E.T. (2014). "Oil Joint Venture Partnerships and Nigerian Economy". University of Nigeria Journal of Political Economy, 7 (1\&2): 1-24.

Ifesinachi, K. and Aniche, E.T. (2015). "The Nigerian National Petroleum Corporation (NNPC) and Enforcement of Zero Gas Flaring Regime in Nigeria”. ANSU Journal of Arts and Social Sciences, 4 (1): 48-74. 
Ifesinachi, K. and Aniche, E.T. (2016). "The Devil's Excreta: Assessing the Impact of Oil Joint Venture Partnerships on the Enforcement of Zero-Gas Flaring Regime in Nigeria". South East Journal of Political Science (SEJPS), 2 (1).

Inner City Fund (ICF) International, "Nigeria: Carbon Credit Development for Flare Reduction" Projects Guidebook, June 2006.

Ismail, O.S. and Umukoro, G.E. (2012). “Global Impact of Gas Flaring”. Energy and Power Engineering, 4: 290 302.

Kaldany, R. (2006). “Global Gas Flaring Reduction: A Time for Action!”. A Keynote Speech Presented at Global Forum on Flaring and Gas Utilization, Held in Paris on December 13.

Kingston, K.G. (2011). "The Dilemmas of Minerals Dependent Economy: The Case of Foreign Direct Investment and Pollution in Nigeria". African Journal of Social Sciences, 1 (1): 1-14.

Kutting, G. (2004). "Globalization and the Environment: Moving Beyond Neo-liberal Institutionalism". International Journal of Peace Studies, 9 (1): 29-41.

Mahdavy, H. (1990). "The Patterns and Problems of Economic Development in Rentier States: The Case of Iran". In M.A Cook (ed.) Studies in Economic History of Middle East, London: Oxford University Press.

Malumfashi, G.I. (2007). "Phase-out of Gas Flaring in Nigeria by 2008: The Prospects of a Multi-win Project". Petroleum Training Journal (PTJ), 4 (1): 1-39.

McCormick, J. (1995). The Global Environmental Movement, London: John Wiley \& Sons.

Molyneux, J. (2010). Marxism and Environmental Crisis, September 7. Retrieved from http://www.swp.ie/comment on 20/09/2011.

Ogbara, N. (2009). "Why the Extant Legal Framework Prohibiting Gas Flare in Nigeria did not Work?” A Paper Presented at a Social Action Organized Forum on Gas Flaring Prohibition and Sustainable Energy Future for Nigeria on September 30 at Bolton White Hotels Ltd, Abuja.

Okafor, J.C. and Aniche, E.T. (2014). "A Critical Appraisal of Enforcement of Nigerian Oil and Gas Industry Content Development (NOGICD) Act, 2010”. Journal of Law, Policy and Globalization (JLPG), 31 : 82-94.

Okeke, V.O.S. and Aniche, E.T. (2013). "The Political Economy of Enforcing Local Content Policy in Nigerian Oil and Gas Sector: An Assessment of the Nigerian National Petroleum Corporation (NNPC), 20062010”. International Journal of Development Studies (IJDS), V (II): 8-19.

Oluduro, O. (2011). "Bureaucratic Rhetoric of Climate Change in Nigeria: International Aspiration Versus Local Realities". Retrieved from http://www.iucnael.org/en/documents on 11/02/2012.

Orenstein, K. (2010). “Capitalizing on Climate: The World Bank's Role in Climate Change and International Climate Finance". In Friends of the Earth (FOE), June.

Parenti, M. (2005). "Why the Corporate Rich Oppose Environmentalism". Retrieved from http://www.energybulletin.org on 20/06/2011.

Podesta, J. and Ogden, P. (2007). Global Warming: The Security Challenges of Climate Change, Washington D.C: Centre for American Progress, November.

Report of the Vision 2020 National Technical Working Group on Energy Sector, 2009.

Svensson, B. and Rios, M.O. (2012). "Global Gas Flaring Reduction Partners Make Progress". Global Forum, June.

Ukala, E. (2011). “Gas Flaring in Nigeria's Niger Delta: Failed Promises and Reviving Community Voices”. Journal of Energy, Climate and Environment, 97: 97-126.

Ukpohor, E.T.O. (2012). "Nigeria Gas Master Plan: Strengthening the Nigeria Gas Infrastructure Blueprint as a Base for Expanding Regional Gas Market". World Gas Conference Technical Paper.

Van Gennip, J. (2006). Energy Security. NATO Parliamentary Assembly Paper.

Varma, S. (2008). "Unlocking the Value of Wasted Natural Gas". A Paper Delivered at Global Forum on Flaring and Venting Reduction and Natural Gas Utilization in Amsterdam, Netherlands, on December 4.

Waisley, S.L. (1998). Projections for US and Global Supply and Demand for 2010 and 2020. A Paper Presented at US and China Oil and Gas Industrial Forum in Beijing, China on November 2-4.

Walker, A. (2011). "Nigeria's Gas Profits up in Smoke". Retrieved from http://news.bbc.co.uk/2/hi/Africa on 28/03/2011.

Woodhouse, K.M. (2009). The Politics of Ecology: Environmentalism and Liberalism in the 1960s. Journal for the Study of Radicalism, 2 (2): 53-84.

World Bank (2002). Regulation of Associated Gas Flaring and Venting. A Global Overview and Lessons from International Experience, World Bank Group Report Number 3, April.

World Bank (2004a). GGFR Initiative Report on Consultations with Stakeholders. The World Bank Paper 27275, A Public-Private Partnership No 1.Washington D.C.: World Bank.

World Bank (2004b) A Voluntary Standard for Global Gas Flaring and Venting Reduction, No. 4.

World Bank (2005). Gas Flaring Reduction Projects Framework for Clean Development Mechanism (CDM) 
Baseline Methodologies, Revised April.

Yersin, D. (2006). Ensuring Energy Security. Foreign Affairs, March/April.

List of Tables

Table 1: GGFR Partners, Countries, Oil Companies and Organizations

\begin{tabular}{|l|l|l|}
\hline Countries & Oil Companies & Organizations \\
\hline Algeria & BP & EU \\
\hline Angola & Chevron & OPEC \\
\hline Azerbaijan & Conoco Phillips & Wartsila \\
\hline Cameroon & Eni & WBG \\
\hline Canada (Donor) & Exxon Mobil & \\
\hline Congo (Republic) & Kuwait Oil Corporation & \\
\hline France & Marathon Oil & \\
\hline Gabon & Maersk Oil and Gas & \\
\hline Indonesia & NNPC & \\
\hline Iraq & Norsk Hydro & \\
\hline Kazakhstan & Pemex & \\
\hline Kuwait & Qatar Petroleum & \\
\hline Mexico & Shell & \\
\hline Nigeria & SNH & \\
\hline Norway (Donor) & SOCAR & \\
\hline Qatar & Sonatrach & \\
\hline Russian Federation & TOTAL & \\
\hline United Kingdom (Donor) & Statoil & \\
\hline United States of America (Donor) & & \\
\hline Uzbekistan & & \\
\hline Source Adapted from & \\
\hline
\end{tabular}

Source: Adapted from the World Bank Group (2011). Culled from Norwegian University of Science and Technology TPG 4140- Natural Gas Project Report, November 2012.

Table 2: Global Gas Flaring Reduction (GGFR) Voluntary Standard

\section{A. Recommended Timeline Implementing the Voluntary Standard}

\begin{tabular}{|l|l|l|}
\hline Recommended Actions & $\begin{array}{l}\text { Number of Years from } \\
\text { Endorsement }\end{array}$ & $\begin{array}{l}\text { Year for Existing } \\
\text { Partners }\end{array}$ \\
\hline GGFR Steering Committee endorses the Standard & & March 23, 2004 \\
\hline $\begin{array}{l}\text { Organizations and governments adopt the endorsed } \\
\text { Standard }\end{array}$ & 1 year & April 1, 2005 \\
\hline $\begin{array}{l}\text { Implement the initial goal for flaring and venting for new } \\
\text { projects }\end{array}$ & 1 year & April 1, 2005 \\
\hline Implement the initial goal for venting existing facilities & $2-4$ years & January 1, 2006-2008 \\
\hline $\begin{array}{l}\text { Organizations and governments publicly report flaring } \\
\text { and venting (if not currently reporting) }\end{array}$ & 2 years & April 1, 2006 \\
\hline Develop Associated Gas Recovery Plan: & & \\
\hline Within operational project boundaries, or & 2 years & January 1, 2006 \\
\hline With expanded project boundaries & 3 years & January 1, 2007 \\
\hline Develop Country Implementation Plan & $2-3$ years & \\
\hline $\begin{array}{l}\text { Implement the initial goal for flaring and plan for existing } \\
\text { projects (unless Plans indicate other timeframe): }\end{array}$ & & January 1, 2010 \\
\hline Within operational project boundaries, or & 5 years & January 1, 2011 \\
\hline With expanded project boundaries & 6 years & January \\
\hline
\end{tabular}

Source: Global Gas Flaring Reduction (GGFR), 2002. 
B. Flaring and Venting Activities Related to the Voluntary Standard

\begin{tabular}{|c|c|c|c|}
\hline Potential Sources of Venting & $\begin{array}{l}\text { Targeted under } \\
\text { Initial Goal of } \\
\text { Standard } \\
\end{array}$ & $\begin{array}{l}\text { Targeted under } \\
\text { Ultimate Goal of } \\
\text { Standard }\end{array}$ & $\begin{array}{l}\text { Not Covered } \\
\text { by Standard }\end{array}$ \\
\hline \multicolumn{4}{|l|}{ Continuous Production Venting } \\
\hline Continuous venting due to lack of flaring facilities & $\mathrm{X}$ & & \\
\hline $\begin{array}{l}\text { Venting of production storage tank losses from: } \\
\text { - } \quad \text { Flashing } \\
\text { - } \quad \text { Working and breathing }\end{array}$ & & $\begin{array}{l}X \\
X\end{array}$ & \\
\hline Gas-driven pneumatic devices & & $\mathrm{X}$ & \\
\hline Gas driven chemical injection pumps & & $\mathrm{X}$ & \\
\hline Gas treatment events & & & $\mathrm{X}$ \\
\hline $\begin{array}{l}\text { Locally vented low pressure-rated systems } \\
\text { include storage tanks or compressor ancillary } \\
\text { systems that are typically vented locally in order } \\
\text { to provide the lowest back-pressure possible }\end{array}$ & & $\mathrm{X}$ & \\
\hline \multicolumn{4}{|l|}{ Non-continuous production venting } \\
\hline Catalyst/mole sieve dryers & & $\mathrm{X}$ & \\
\hline $\begin{array}{l}\text { Oil well completion, treatment, stimulation, } \\
\text { workover, and testing }\end{array}$ & & $\mathrm{X}$ & \\
\hline Surface casing gas (oil wells) & & $\mathrm{X}$ & \\
\hline Gas migration (oil wells) & & $\mathrm{X}$ & \\
\hline $\begin{array}{l}\text { Operational venting used in order to bring the } \\
\text { pressure in specific equipment items to } \\
\text { "atmospheric level" for example compressor seal } \\
\text { systems, pig launchers/receivers, chemical skids, } \\
\text { and so forth. }\end{array}$ & & $\mathrm{X}$ & \\
\hline Venting to clear vessels for personnel entry & & & $\mathrm{X}$ \\
\hline $\begin{array}{l}\text { Well stimulation/venting/unloading (field } \\
\text { venting) }\end{array}$ & & $\mathrm{X}$ & \\
\hline
\end{tabular}

Source: Global Gas Flaring Reduction (GGFR), 2002.

C. Flaring Activities Subject to the Voluntary Standard

\begin{tabular}{|l|l|l|l|}
\hline Potential Sources of Flaring & $\begin{array}{l}\text { Targeted } \\
\text { Initial Goal of } \\
\text { Standard }\end{array}$ & $\begin{array}{l}\text { Targeted } \\
\text { Ultimate Goal of } \\
\text { Standard }\end{array}$ & $\begin{array}{l}\text { Not } \\
\text { Covered by } \\
\text { Standard }\end{array}$ \\
\hline Continuous production flaring & & & \\
\hline $\begin{array}{l}\text { Non-safety flaring due to lack of } \\
\text { processing facilities and/or marketing } \\
\text { outlets }\end{array}$ & $\mathrm{X}$ & & \\
\hline Non-continuous production flaring & & $\mathrm{X}$ & \\
\hline $\begin{array}{l}\text { Compressor start-ups and shutdowns } \\
\text { Well completion, treatment, stimulation, } \\
\text { workover, and testing: }\end{array}$ & $\mathrm{X}$ & $\mathrm{X}$ & \\
\hline $\begin{array}{l}\text { Short term (<30 days) } \\
\text { Long term (>30days) }\end{array}$ & $\mathrm{X}$ & & \\
\hline Early Production Facilities & $\mathrm{X}$ & & $\mathrm{X}$ \\
\hline Surface casing gas (oil wells) & & $\mathrm{X}$ & \\
\hline Gas Migration (oil wells) & & & \\
\hline $\begin{array}{l}\text { Flaring of production storage tank losses } \\
\text { from: }\end{array}$ & & & \\
\hline Flashing & & & \\
\hline
\end{tabular}

Source: Global Gas Flaring Reduction (GGFR), 2002. 
Table 3: Current Gas Flaring Reduction CDM Projects

\begin{tabular}{|l|l|l|l|}
\hline Title & Country & $\mathbf{K t C O}_{2} / \mathbf{Y}$ & $\mathbf{2 0 1 2}_{\mathbf{k t C O}}$ \\
\hline Use of Recovered Gas for Methanol Production & Equatorial Guinea & $2,356.03$ & 23,560 \\
\hline Recovery of AG Kwale Oil Gas Process Plant & Nigeria & $1,496.93$ & 10,521 \\
\hline The Ovade Ogharefe Gas Capture and Processing Project & Nigeria & $2,531.70$ & 14,505 \\
\hline A1-Shaheen Oil Field Gas Recovery and Utilization Project & Qatar & $1,457.81$ & 9,120 \\
\hline
\end{tabular}

Source: Gouvello (2011). Culled from Norwegian University of Science and Technology TPG 4140 - Natural Gas Project Report, November 2012.

Table 4: GGFR Partner Countries and Projects

\begin{tabular}{|l|l|l|}
\hline Partner Countries & Projects & Carbon Credit Options \\
\hline Algeria & f fields: Ohanet, TFT and In Amenas & $\begin{array}{l}\text { Exploring carbon credits for the three } \\
\text { fields }\end{array}$ \\
\hline Nigeria & 2 projects: gas pipeline and gas to power & 2 power projects: AFAM and Kwale \\
\hline Angola & Angola LNG & Angola LNG \\
\hline Cameroon & Rio del Rey pipeline to Limbe & \\
\hline Equatorial Guinea & Zafiro pipeline to ELNG & \\
\hline Chad & Sedigui & \\
\hline Russia & Gas projects in Khanty-Mansiysk & Gas to Power Surgut, TNK-BP \\
\hline Indonesia & To be developed & To be developed \\
\hline
\end{tabular}

Source: Svensson, B. (2005). Gas Flaring Reduction Global Perspective. National Gas Star Program. Annual Implementation Workshop, October 25.

Table 5: World Bank Credit Facilities to Nigeria

\begin{tabular}{|l|l|l|}
\hline Date & Project Name & Credit Facilities in \$ \\
\hline June 28, 2005 & National Energy Development Project (NEDP) & 172 \\
\hline August 06, 2007 & National Energy Development Project (Carbon Offset) & 5.87 \\
\hline June 09, 2008 & NG-Lagos Landfill Gas and Composing (FYO6) & 2.13 \\
\hline June 16, 2009 & Nigeria Electricity and Gas Improvement Project (NEGIP) & 200 \\
\hline
\end{tabular}

Source: World Bank Statistics, 2011.

Table 6: GGFR's Flaring Reduction Demonstration Project from Carbon Finance in Nigeria

\begin{tabular}{|l|l|l|l|l|l|l|}
\hline Company & Project & Project Type & $\begin{array}{l}\text { CER/EUR y } \\
(\mathrm{k})\end{array}$ & $\begin{array}{l}\text { CER/EUR 2012 } \\
(\mathrm{k})\end{array}$ & Status & Method \\
\hline Eni & Kwale & Gas-to-Power & 1,513 & 10,540 & Registered & AM0009 \\
\hline Shell & Afam & Gas-to-Power & 740 & 3,700 & $\begin{array}{l}\text { Method } \\
\text { submitted }\end{array}$ & NM \\
\hline Eni & ObOb & $\begin{array}{l}\text { Gas to } \\
\text { Reinjection }\end{array}$ & 2,000 & 10,000 & On hold & NM \\
\hline
\end{tabular}

Source: GGFR-CFFS Committee Workshop, GGFR Brief, April 25, 2007.

Table 7: Total Gas Produced and Flared (mscf) 2001-2011

\begin{tabular}{|l|l|l|l|}
\hline Year & Gas Produced & Gas Flared & Percentage Gas Flared \\
\hline 2001 & $1,822,922,111$ & $920,905,671$ & 50.52 \\
\hline 2002 & $1,651,591,488$ & $744,108,036$ & 45.65 \\
\hline 2003 & $1,830,302,769$ & $847,614,682$ & 46.31 \\
\hline 2004 & $2,082,283,189$ & $886,070,555$ & 42.55 \\
\hline 2005 & $2,093,628,859$ & $812,332,777$ & 38.80 \\
\hline 2007 & $2,182,432,084$ & $799,998,369$ & 36.66 \\
\hline 2008 & $2,140,274,706$ & $659,368,435$ & 30.81 \\
\hline 2009 & $2,282,440,395$ & $617,618,876$ & 27.06 \\
\hline 2010 & $1,837,278,307$ & $509,351,905$ & 27.72 \\
\hline 2011 & $2,392,838,898$ & $581,568,354$ & 24.30 \\
\hline
\end{tabular}

Source: NNPC Annual Statistical Bulletin 2010 and 2011. 
Table 8: Nigeria's Estimated Flared Volumes (in bcm) from Satellite Data, 2002-2011

\begin{tabular}{|l|l|l|l|l|l|}
\hline Year & F14 & F15 & F16 & F18 & Average \\
\hline 2002 & 21.1 & 21.0 & - & - & 21.0 \\
\hline 2003 & 23.1 & 24.6 & - & - & 23.8 \\
\hline 2004 & - & 21.9 & 23.4 & - & 22.6 \\
\hline 2005 & - & 20.0 & 22.5 & - & 21.3 \\
\hline 2006 & - & 17.6 & 19.7 & - & 18.6 \\
\hline 2007 & - & 15.5 & 17.0 & - & 16.3 \\
\hline 2008 & - & - & 15.5 & - & 15.5 \\
\hline 2009 & - & - & 14.9 & - & 14.9 \\
\hline 2010 & - & - & - & 15.2 & 15.0 \\
\hline 2011 & - & - & - & - & 14.6 \\
\hline
\end{tabular}

Source: National Oceanic and Atmospheric Administration (NOAA) Satellite Data, 2012. 